\title{
The Right of Access to Port and the Impact of Historic Fishing Rights
}

\author{
Arron N. Honniball*
}

\section{Introduction}

DILA's 2020 International Conference theme, "Reshaping International Law in the Asian Century", does not necessitate the challenging or subversion of established norms. Reshaping may equally occur by reflecting on overlapping fragments of international law that were previously only analyzed in silos. This article identifies a previously overlooked contribution to international law by taking historic fishing rights, a predominantly regional or bilateral custom, and assessing the extent to which it refines the lack of customary law rights for vessels to access foreign ports, an established global norm of international law.

This article therefore first proceeds with section 2 charting the lack of any general right of access to foreign ports in the law of the sea. The only widely accepted customary law exception concerns vessels in distress, or a situation of force majeure, where access to port is necessary to preserve human life. Section 3 then introduces the contemporary scope of historic fishing rights, and, more specifically, the recognition of associated rights in the Eritrea/ Yemen - Sovereignty and Maritime Delimitation in the Red Sea Award Stage II (Eritrea/Yemen Award). ${ }^{1}$ The explicit example of an associated right of access to port for historic fishers necessitates a refinement of the findings in section 2. The conclusion shall place this exceptional right of entry within its wider international law context, namely as an affirmative example of bilateral customary international law. ${ }^{2}$

Finally, this article concerns the practice of international courts and tribunals in conceptually recognizing a historic fisher's associated right of access to a port in the law of the sea. This article does not provide an exhaustive account of historic fishing regimes in which an associated access right could apply.

* Research Fellow (Ocean Law and Policy), Centre for International Law, National University of Singapore.

1 Maritime Boundary Delimitation (Eri./Yemen), 22 R.I.A.A. 335 (Perm. Ct. Arb. 1999). The author is grateful for the constructive comments received on a previous draft by colleagues, participants at the 2020 DILA International Conference and during peer review.

2 A hypothetical regional custom variant is not discussed here. 
Further refinements beyond the focus of this article may also apply, such as international trade law or health regulations. ${ }^{3}$

A foreign vessel's right of access to port would operate as a limitation to the otherwise applicable port state's jurisdiction. A port state is a state exercising jurisdiction over a foreign vessel visiting its port. Analyzing access rights therefore first requires reviewing what 'port' encapsulates, as well as the port state jurisdiction potentially affected.

\subsection{Ports}

In common parlance, ports are defined by synonyms or common features, such as a harbor, wharf, or seaport. Fishing ports are more diverse, sometimes lacking any port facilities normally associated with shipping. For example, fishing ports would include beach landing areas. The United Nations Convention on the Law of the Sea (UnClos) refers to ports without definition. ${ }^{5}$ The Agreement on Port State Measures to Prevent, Deter and Eliminate Illegal, Unreported and Unregulated Fishing (PSMA) defines ports as including analogous "offshore terminals and other installations" 6 where port services are available. Ports are thus simply locations equipped to enable vessels to visit a state and/or access port services. This definition is without prejudice to the existence of any specific infrastructure or port services.

For international lawyers this broad definition is sufficient. The term port in "access to port" or "port state jurisdiction" identifies the state with rights,

3 E.g., Treaty Between Australia and the Independent State of Papua New Guinea Concerning Sovereignty and Maritime Boundaries in the Area Between the Two Countries, Including the Area Known as Torres Strait, and Related Matters art. 16 Dec. 18, 1978, [1985] ATS 4 (entered into force Feb. 15, 1985) [hereinafter Torres Strait Treaty]; Coronavirus (COVID-19) Information \& Updates, Torres Strait Island Regional Council, http://www.tsirc .qld.gov.au/coronavirus (indicating that this article was implemented since February 2020 in response to COvID-19, including restrictions on cross-border movement).

4 Arron N. Honniball, Extraterritorial Port State Measures: The Basis and Limits of Unilateral Port State Jurisdiction to Combat Illegal, Unreported and Unregulated Fishing 140-48 (2019) (Ph.D. dissertation, Utrecht University) (ResearchGate) (this section incorporates and builds on parts 4.2.1-4.2.3 of the author's Ph.D. manuscript).

5 United Nations Convention on the Law of the Sea arts. 11, 18(1), Dec. 10, 1982, 1833 U.N.T.s. 397 [hereinafter UNCLOS].

6 Agreement on Port State Measures to Prevent, Deter and Eliminate Illegal, Unreported and Unregulated Fishing art. 1(g), Nov. 22, 2009, 55 I.L.M. 1157 [hereinafter PSMA]. 
responsibilities, and limitations concerning the exercise of jurisdiction. In international trade law ports are comparable to land-based ports of entry. ${ }^{7}$ Concerning the law of the sea, ports "form a convenient point at which to exercise control over [visiting] vessels". ${ }^{\text {. }}$

Ports are not a distinct maritime zone. ${ }^{9}$ Many ports are located in closed bays or rivers that are landward of the baselines used to measure the breadth of the territorial sea. ${ }^{10}$ Internal waters are those waters landward "of the baseline of the territorial sea".11 A port's infrastructure may extend out to sea, in which case the "outermost permanent harbor works which form an integral part of the harbor system are regarded as forming part of the coast". ${ }^{2}$ This will impact the drawing of baselines and therefore the delineation of a coastal state's maritime zones. ${ }^{13}$ The PSMA likewise refers to a state's territory as including its ports. ${ }^{14}$ Ports (and foreign vessels therein) are therefore often located in a state's territory or internal waters..$^{15} \mathrm{~A}$ coastal state has sovereignty over its internal waters comparable to that exercised over its land territory. ${ }^{16}$

Ports may also be located in the territorial sea and archipelagic waters. ${ }^{17}$ The territorial sea actually extends to roadsteads that would otherwise be wholly or partially located beyond the outer limits of the territorial sea. ${ }^{18} \mathrm{~A}$ coastal state's sovereignty, subject to UNCLOS and other pertinent international law, extends to the territorial sea and archipelagic waters. ${ }^{19}$

Finally, UNCLOS recognizes offshore loading and unloading points for exploration or exploitation of the exclusive economic zone (EEZ) and continental

Erik J. Molenaar, Port State Jurisdiction, 2021 Max Planck Encyclopedia of Public InTERnational LaW, pt. A, ๆ 1 .

8 Bevan Marten, Port State Jurisdiction and the Regulation of International Merchant Shipping 21 (2013).

$9 \quad$ Id. at $22-25$.

10 Stuart Kaye, The Proliferation Security Initiative in the Maritime Domain, 81 InternaTIONAL LAW STUdies 141, 144 (2006); See UnClos, supra note 5, arts. 9-10.

11 UNCLOS, supra note 5, arts. 8(1), 50 (stating that closing lines may also delimit internal waters within archipelagic waters).

$12 I$ Id. arts. 11, 216(1)(c) (stating that the loading occurs "[w] ithin its territory [ports] or at its off-shore terminals").

13 Id. arts. 5, 7.

14 PSMA, supra note 6, pmbl., art. 4(1)(b).

15 Gordon Earl Dunfee, Territorial Status of Deepwater Ports, 15 San Diego Law Review 6о3, 612-13 (1978).

16 UNCLOS, supra note 5 , art. 2(1).

17 Id. arts. 18(1), 25(2), 211(3), 216(1)(c), 218(1), 218(3), 219, 220(1) (off-shore terminals are treated alike, but are not part of the coast).

18 Id. art. 12.

19 Id. arts. 2(1), 2(3), 34(2), 49. 
shelf. ${ }^{20}$ These offshore points, as well as other exceptional deep-water ports in the EEZ or the high seas, are not used in historic fisheries. Nevertheless, the port state will limit the entry of vessels to those flag states for which a relevant bilateral arrangement on access and jurisdiction exists. Bilateral agreements between flag states and the USA provide the USA with treaty-based port state jurisdiction for its extraterritorial ports analogous to that exercised over territorial ports. ${ }^{21}$

\subsection{Port State Prescriptive Jurisdiction on Port Entry}

A port state's prescriptive jurisdiction may be separated into two strands, namely; (1) the regulation of access to port and port services (e.g. landing, transshipping, packaging, processing, refueling, resupplying, maintenance, and drydocking), and; (2) the regulation of port offenses and other exercises of state jurisdiction in international law (e.g. territorial jurisdiction, protective jurisdiction or treaty-based jurisdiction).

This article concerns the regulation of access to port and port services which is best seen as a domaine réservé exception to the law of state jurisdiction. ${ }^{22}$ Contemporary port state practice on access, while universally accepted as legal among states, does not follow the nexus-based approach of state jurisdiction in international law. Port entry conditions may be prescribed concerning conduct wherever and whenever it occurs. This includes imposing conditions of extraterritorial conduct with no nexus to the port state, let alone a sufficient nexus to fulfill the requirements of applying the principles of objective or subjective territorial jurisdiction. This is analogous to the legal basis for prescribing conditions of entry for foreign nationals entering a state. ${ }^{23}$

20 Id. arts. 56, 60, 80; Henrik Ringbom, National Employment Conditions and Foreign Ships International Law Considerations, 456 SCANDinavian Institute of Maritime Law YEARBOOK 109, 139-42 (2015).

2133 U.s.C. $§ 1518$; Gero Brugmann, Access to Maritime Ports 57-58 (2003) (Ph.D. dissertation, University of Hamburg) (on file with author); e.g., Exchange of Letters Constituting an Agreement Concerning the Louisiana Off-Shore Oil Port (LOOP) (with Annex), Fr.-U.S., Mar. 24, 1983, 1437 U.N.T.s. 61; Dunfee, supra note 15, at 613.

22 Honniball, supra note 4, at 71-88; Tom Ruys \& Cedric Ryngaert, Secondary Sanctions: A Weapon out of Control? The International Legality of, and European Responses to, US Secondary Sanctions, 2020 British Yearbook of International LaW 11-16, https://academic.oup.com/bybil/advance-article/doi/10.1093/bybil/braaoo7/5909 823 ?searchresult=1.

23 Protocol Against the Smuggling of Migrants by Land, Sea and Air, Supplementing the United Nations Convention Against Transnational Organized Crime art. 3(b), Nov. 15, 2000, 2241 U.N.T.S. $5^{\circ} 7$ (stating that the requirements may be prescribed without the need to fulfill any nexus threshold as required in state jurisdiction: "Illegal entry' shall 
Countless multilateral instruments recognize a broad right to regulate entry into port or access to port services, including the International Convention for the Safety of Life at Sea (SOLAS), ${ }^{24}$ International Convention for the Prevention of Pollution From Ships (MAR POL), ${ }^{25}$ UNCLOS, ${ }^{26}$ Salvage Convention, ${ }^{27}$ United Nations Fish Stocks Agreement (UNFSA), ${ }^{28}$ PSMA,${ }^{29}$ Hong Kong Convention, ${ }^{30}$ Convention on Facilitation of International Maritime Traffic (FAL), ${ }^{31}$ and International Health Regulations (IHR). ${ }^{32}$ Supplementary instruments, including the International Codefor the Security of Ships and of Port Facilities, ${ }^{33}$ reaffirm the right to deny entry to a port. Within fisheries law, port entry conditions may concern the manner of high seas fishing conducted by foreign vessels. For example, entry conditions may address whether the vessel's conduct is deemed by the port state to have undermined a conservation and management measure of a Regional Fisheries Management Organization or Arrangement (RFMO/A), or is deemed illegal, unreported, or unregulated (IUU) fishing. ${ }^{34}$

mean crossing borders without complying with the necessary requirements for legal entry into the receiving State").

24 International Convention for the Safety of Life at Sea ch. XI-2, Regulation 9/2.2, 2.5.4, Nov. 1, 1974, 1184 U.N.T.S. 276 [hereinafter SOLAS].

25 International Convention for the Prevention of Pollution from Ships art. 5(3), Feb. 17, 1978, 1340 U.N.T.S. 184.

26 UNCLOS, supra note 5, arts. 25(2), 211(3), 255.

27 International Convention on Salvage art. 9, Apr. 28, 1989, 1953 U.N.T.s. 165 [hereinafter Salvage Convention].

28 Agreement for the Implementation of the Provisions of the United Nations Convention on the Law of the Sea of 10 December 1982 Relating to the Conservation and Management of Straddling Fish Stocks and Highly Migratory Fish Stocks art. 23, Aug. 4, 1995, 2167 U.N.T.S. 3 [hereinafter UNFSA].

29 PSMA, supra note 6, arts. 4(1)(b), 7-9.

30 Int'l Maritime Org. [IMO], SR/CONF/45, Hong Kong International Convention for the Safe and Environmentally Sound Recycling of Ships, art. 9(3) (May 15, 2009), https://www.imo. org/en/OurWork/Environment/Pages/Ship-Recycling.aspx.

31 Convention on Facilitation of International Maritime Traffic art. 5, Apr. 9, 1965, 591 U.N.T.S. 265 [hereinafter FAL].

32 International Health Regulations arts. 28, 43, May 23, 2005, 2509 U.N.T.s. 79 [hereinafter IHR].

33 Imo, solas/Conf.5/34, Consideration and Adoption of the International Ship and Port Facility Security (ISPS) Code (Dec. 17, 2002), https://www.imo.org/en/OurWork/Security/ Pages/SOLAS-XI-2\%2OISPS\%20Code.aspx; IMO, MSC/Circ.1111, Guidance Relating to the Implementation of SOLAS Chapter XI-2 and the ISPS Code, ๆ ๆ 3.2, 3.5.4, 3.8.2-.4 (June 7, 2004), https://wwwcdn.imo.org/localresources/en/OurWork/Security/Documents/MSC .Circ.1111.pdf.

34 E.g., Western \& Central Pacific Fisheries Commission [WCPFC], Conservation and Management Measure on Minimum Standards for Port State Measures, at 3-4, WCPFC Doc. CMM 2017-O2 (Dec. 7, 2017). 
The customary law breadth and basis of port state discretion over entry are evident in the lack of any treaty-based jurisdiction within these instruments, as well as their application to non-contracting parties' vessels where flag state consent is absent. Port state control regimes equally apply instruments to visiting vessels regardless their flag state or ratification status. ${ }^{35}$

\subsection{Port State Enforcement Jurisdiction on Port Entry}

The exceptional domaine réservé-based right to regulate access to port and port services is, in turn, limited in its enforcement to the denial of access to port or port services. The denial of entry to port or the denial of port services is seen as an enforcement measure. ${ }^{36}$ Other enforcement measures, such as fines, imprisonment, or confiscation of catch and vessel would not fall within this domaine réservé exception and are thus reserved for validly prescribed port state offense (strand (2) in subsection 2.2 above). ${ }^{37}$

While the scope of a coastal state's enforcement jurisdiction significantly differs depending on the maritime zone in which enforcement occurs, a port state's enforcement jurisdiction is largely consistent regardless of where the port is located. Within internal waters, no general right of navigation exists which would limit port state jurisdiction. ${ }^{38}$ Within other maritime zones, the navigation rights that limit coastal state enforcement are inapplicable once the vessel requests entry into port or enters a port therein. ${ }^{39}$

Outside of the port limits, an inbound foreign vessel may exercise innocent passage in the territorial sea. However, this is subject to the coastal state's measures necessary to enforce its conditions of port entry. ${ }^{40}$ If it is demonstrable that a vessel is proceeding to port and a coastal state's measures are necessary

35 Memorandum of Understanding on Port State Control in the Asia-Pacific Region, § 2.5, at 4, Nov. 6, 2018, http://www.tokyo-mou.org/doc/Memorandum\%2orev18.pdf.

36 твR Proceedings Concerning Chilean Practices Affecting Transit of Swordfish in Chilean Ports, in report dated Mar. 23, 1999 from European Commission to the Trade Barriers Regulation Commission, at 32 (Mar. 23, 1999).

37 See Arron N. Honniball, What's in a Duty? EU Identification of Non-Cooperating Port States and Their Prescriptive Responses, 35 The International Journal of Marine \& COASTAL LAW 19, 35-40 (2020) (indicating the examples of port state offenses from the Asian region).

38 UNCLOS, supra note 5, art. 18(1); (stating that innocent passage ends at the baselines, with no corresponding navigational rights within internal waters, bar); id. art. 8(2); id. art. 18(1)(a) (showing that upon calling at port this limited exception would extinguish by analogy to port calls outside internal waters).

39 Id. arts. 18(1), 52; $i d$. art. 53(3) (showing that the right of archipelagic sea lanes passage is inapplicable as it is limited to vessels traversing from and to the $\mathrm{EEZ} / \mathrm{high}$ seas).

Id. arts. 25(2), 52(1), 211(3). 
and preventative, the vessel may be treated as "akin to vessels engaged in noninnocent passage" for the purposes of enforcement. ${ }^{41}$ Concerning outbound vessels, enforcement jurisdiction remains at the coastal state's discretion. ${ }^{42}$ For example, vessels violating port state measures could be subject to hot pursuit and enforcement measures at sea. ${ }^{43}$

\section{$2.4 \quad$ Access to Port by Foreign Vessels}

The finding that a port state has an exceptional domaine réservé-based right to condition and deny access to port provides an unlimited jurisdictional basis in international law. However, beyond establishing a valid legal basis, a port state must also comply with any other obligations assumed under international law which may limit the scope and exercise of its jurisdiction. Where the law of the sea provides foreign vessels with a right of entry into port, the corresponding obligation upon port states would limit port state jurisdiction. An otherwise legal basis to deny access to port may also be legally constrained by other examples not examined here, including obligations under human rights instruments, ${ }^{44}$ the International Convention on Maritime Search and Rescue, or the Refugee Convention. ${ }^{45}$

41 Richard Barnes, United Nations Convention on the LaW of the Sea: A Commentary 222 (Alexander Proelss ed., 2017).

42 UNCLOS, supra note 5 , arts. $27(2), 28(3)$.

43 Id. arts. 111(1), (8) (indicating anticipated hot pursuit commenced in internal waters); see also Nicholas M. Poulantzas, The Right of Hot Pursuit in International LAW 151-54 (2d ed. 2002) (showing examples of 'vertical passage').

44 Efthymios Papastavridis, European Convention on Human Rights and the Law of the Sea:The Strasbourg Court in Unchartered Waters?, 12 QUEEN MARY STUDIES IN INTERNATIONAL Law, the Interpretation \& Application of the European Convention of HUMAN Rights 115 passim (2013) (succinctly stating how law of the sea rights and human rights obligations interact).

45 Felicity G. Attard, The Duty of the Shipmaster to Render Assistance at Sea Under International Law, 41 Queen Mary Studies in International LaW 29 passim (2020); see Valentin J. Schatz \& Marco Fantinato, Post-Rescue Innocent Passage by Non-Governmental Search and Rescue Vessels in the Mediterranean, 35 The International Jounral of MARINE \& CoAStAL LAW 740, 749 (2020); Richard Barnes, The International Law Of The Sea And Migration Control, 21 Immigration \& Asylum LaW \& Policy in Europe 103, 119 (2010); see generally Richard L. Kilpatrick \& Adam Smith, Balancing the SAR Responsibilities of States and Shipmasters, 46 Immigration \& Asylum Law \& Policy IN Europe 81, 82-85 (2020); see generally Seline Trevisanut \& Salvatore Nicolosi, Saving Lives in the Mediterranean: A Legal Analysis of Aquarius-like Incidents, 2019 Ars AEQuI 121, 122 (2019) (stating that states have conflicting interpretations). 


\subsubsection{A General Right of Entry to Port}

Prescribed port entry conditions would be unenforceable through denial of entry if said denial conflicts with a foreign vessel's right of access. Historically, a right of port entry was the subject of a lively debate. ${ }^{46}$ Commentators and state practice have largely concluded no such general right exists. ${ }^{47}$ Indeed, in fisheries law quite the opposite is apparent. Port states party to PSMA are obliged to deny a foreign fishing vessel access to port if sufficient evidence suggests the vessel has engaged in IUU fishing or fishing-related activities in support of IUU fishing. ${ }^{48}$

In fisheries law the debate on access occasionally resurfaces. In 2016 a proposal sought to amend an RFMO Conservation Measure by exempting certain vessels from submitting documentation as a port entry requirement. This was based upon the "right of a vessel to peaceful entry into port is enshrined in international maritime law".49 Other states disagreed and the proposal failed to gain support. ${ }^{50}$ Equally unsuccessful have been attempts in domestic courts

46 See generally Myres S. McDougal \& William T. Burke, The Public Order of the Oceans: A Contemporary International LaW of the Sea 103-17 (1987); A. Vaughan Lowe, The Right of Entry into Maritime Ports in International Law, 14 SAN Diego Law Review 597 (1976); Louise de La Fayette, Access to Ports in International Law, 11 The International Journal of Marine \& Coastal Law 1 (1996); Anthony Morrison, Places of Refuge for Ships in Distress: Problems and Methods of Resolution 53-74 (2012); BRUgmanN, supra note 21, at 123-24; Vasilios Tasikas, The Regime of Maritime Port Access: A Relook at Contemporary International and United States Law, 5 Loyola Maritime Law Journal 1 (2007); Benjamin Parameswaran, The Liberalization of Maritime Transport Services: With Special Reference to the WTO/GATS Framework 127-4o (2004); Ian J. Booth, International Ship Pollution Law: Recent Developments at UNCLOS, 4 MARINE PoliCy 215, 225 (1980) (discussing both sides on the matter).

47 MCDougal \& BuRKe, supra note 46, at 117 (as well as numerous other texts recognizing the established exceptions of force majeure or treaty-based rights of access); e.g., William D. Baumgartner \& John T. Oliver, Conditions on Entry of Foreign-Flag Vessels into US Ports to Promote Maritime Security, 84 International Law Studies 33 (2008).

48 PSMA, supra note 6, art. 9(4).

49 Commission for the Conservation of Antarctic Marine Living Resources [CCAMLR], Proposal by Ukraine to Amend CCAMLR Conservation Measure 10-05 on the Dissostichus Catch Documentation Scheme, CCAMLR Doc. No. CCAMLR-XXXv/29 (2016) (reference was also made to innocent passage, but as noted, this is inapplicable).

50 E.g., CCAMLr, Report of the Thirty-Fifth Meeting of the Commission, at 5, CCAMLr Doc. No. CCAMLR-XXXV (Oct. 28, 2016) (stating that Chile "could not agree to proposals that seek to undermine Port States' rights to establish certain requirements for port access"); $i d$. at 155 (stating that other states also expressed reservations). 
to challenge the legality of port state measures by arguing an international lawbased right to port access..$^{51}$

In short, even the presumption of access being granted for peaceful and compliant merchant vessels does not extend to fishing vessels. ${ }^{52}$ In 1958, an arbitral tribunal had reasoned that "[a]ccording to a great principle of public international law, the ports of every State must be open to foreign merchant vessels and can only be closed when the vital interest of the State so require". ${ }^{53}$ This reasoning has however been overtaken by contrary practice, ${ }^{54}$ and in any event, did not stand for a general right. ${ }^{55}$ Likewise, the Convention and Statute on the International Régime of Maritime Ports, while sometimes argued as providing a right of port entry, neither represents customary law nor provides a right of entry for contracting parties. ${ }^{56}$ In any event, fishing vessels were excluded from the reciprocity provided..$^{57}$

Fishing vessels are also often excluded or further qualified in bilateral access agreements, ${ }^{58}$ most recently including the EU/UK Trade And Cooperation

51 Omunkete Fishing (Pty) Ltd. v. Minister of Fisheries [2008] NZHC 968 at [40] per Mallon J. (N.z.).

52 Lowe, supra note 46, at 621-22; John T Oliver, Legal and Policy Factors Governing the Imposition of Conditions on Access to andJurisdiction over Foreign-Flag Vessels in U.S. Ports, 5 South Carolina Journal of International LaW \& Business 209, 214-15 (2009); Henning Jessen, Sanctions Compliance Risks in International Shipping: Closure of Five Crimean Ports, the Sanctions Regime in Respect of Ukraine/Russia and Related Compliance Challenges, in Maritime LAW in Motion 289, 301-02 (Proshanto K. Mukherjee et al. eds., 2020).

53 Saudi Arabia v. Arabian American Oil Co., 27 I.L.R. 117, 212 (High Ct. 1958).

54 E.g., Hovrätt [HovR] [Court of Appeals] 2006 p. 67 M8471-o3 (Swed.) (indicating the arguments of the Swedish Environmental Protection Agency); Havet Havsmiljö Kommissionens [Sea Environment Commission], Tid För En Ny Strategi [Time for a New Strategy] 268 (2003) (Swed.) (concluding that there is no right of entry).

55 Kai Trümpler, United nations Convention on the law of the Sea: a Commentary 84, ๆ ๆ 17-19 (Alexander Proelss ed., 2017) (stating that vital interests are undefined and subject to national interpretation. Trümpler argues ARAMCO only stood for non-discrimination).

56 See Convention and Statute on the International Regime of Maritime Ports art. 2, Dec. 9, 1923, 58 L.N.T.S. 285 (providing equality of treatment only on the basis of reciprocity).

57 Id. art. 14.

58 MCDougal \& Burke, supra note 46, at 109-10; Francisco Vicuña, Port State Jurisdiction in Antarctica: A New Approach to Inspection, Control and Enforcement, in IM PLEMENTING the Environmental Protection Regime for the Antartic 45, 59-6o (Davor Vidas ed., 2000) (stating that even when States do establish rights of entry under bilateral treaties, coastal States will usually retain the right to deny entry when vital interests are threatened); Barnes, supra note 45, at 118. 
Agreement.${ }^{59}$ Indeed, a vast collection of bilateral access agreements would be superfluous if a general right to port entry existed. ${ }^{60}$ As treaty-based rights of entry for foreign vessels are a derogation from the port state's rights, the scope of the rights conferred will be restrictively interpreted to only include the classification of vessel, such as merchant vessels or warships, which are clearly identified. ${ }^{61}$

Further contemporary practice accepts the legality of closing ports to foreign vessels unless, as occurred with Ukraine's 2014 closure of five ports located in Russian-controlled Crimea, a dispute over territorial sovereignty exists. ${ }^{62}$ The recent Arctic Science Agreement promotes territorial and port access, but via soft commitments of facilitating access through "best efforts". ${ }^{63}$ This non-binding language, similar to that seen in FAL, ${ }^{64}$ once again highlights the lack of port access rights. The IHR, with 196 States Parties, ${ }^{65}$ provides for the free pratique of foreign vessels in the context of public health responses

59 Trade and Cooperation Agreement Between the European Union and the European Atomic Energy Community, of the One Part, and the United Kingdom of Great Britain and Northern Ireland, of the Other Part art. SERVIN.5.46(1)(a), at 126-27, Dec. 30, 2020 (stating no less favourable treatment on access to port for international maritime transport services).

6o Erik J. Molenaar, Port State Jurisdiction: Toward Comprehensive, Mandatory and Global Coverage, 38 Ocean Development \& International LaW 225, 227 (2007); Erik J. Molenaar, Port and Coastal States, in The Oxford Handbook OF THE LAW OF THE SEA 280 (Donald Rothwell et al. eds., 2015); Ted L. McDorman, Port State Enforcement: A Comment on Article 218 of the 1982 Law of the Sea Convention, 28 Journal of Maritime LaW \& Commerce 305, 310-11 (1997); Brugmann, supra note 21, at 5, 32; MARTEN, supra note 8, at 31-35; HaijIANG YANG, JURISDiction of the Coastal State over Foreign Merchant Ships in Internal Waters AND THE Territorial SEA 48-70 (2006).

61 See Access to, or Anchorage in, the Port of Danzig, of Polish War Vessels, Advisory Opinion, 1945 P.C.I.J. (ser. A/B) No 43, at 142 (Dec. 11) (showing distinction of a treaty provision granting the use of port for commercial purposes from the lack of any right of access and anchorage for war vessels).

62 Jessen, supra note 52, at 289; Lester H. Woolsey, Closure of Ports by the Chinese Nationalist Government, 44 AMERICAN Journal of InTERnATIONAL LAW 350, 353 (1950) (indicating that if insurgents take control of a port the government may not be able to close the port to third states and must instead rely on blockades).

63 Agreement on Enhancing International Arctic Scientific Cooperation art. 4, May 11, 2017, T.I.A.S. No. $18-523$.

64 FAL, supra note 31 , arts. I, v; id. Annex $\S 62.12$ (stating that facilitation of traffic by reducing requirements on port arrival and avoiding unnecessary restrictions on port entry).

$65 I d$. Annex $\S 64.1$ (stating that non-parties to IHR shall endeavour to apply IHR to international shipping). 
by Contracting Parties, including access to port. ${ }^{66}$ However, free pratique is limited to not refusing permission to enter port "for public health reasons" and may still be subject to conditions of entry or specified ports. ${ }^{67}$ Additional health measures, including denial of entry, may apply in response to "specific public health risks or public health emergencies of international concern".68

The COVID-19 pandemic and the response of many port states to prohibit or severely restrict access have demonstrated the lack of any general right of port access. ${ }^{69}$ Technological innovations and automation in shipping may result in further restrictions on access to a port, be it to promote a transition to marine autonomous surface ships (MASS) or because future autonomous ports may be ill-equipped to address non-MAss vessels. ${ }^{70}$

\subsubsection{A Force Majeure or Distress Related Right of Entry to Port}

One exception to 2.4.1 (above) is the customary right of access to port, or another sheltered area, when vessels are in distress or compelled by force majeure, to access port. Access must be necessary to preserve human life. ${ }^{71}$

66 IHR, supra note 32, arts. 1, 28; who \& imo, A Joint Statement on the Response TO THE COVID-19 OUtBREAK 1 (2020), https://wwwcdn.imo.org/localresources/en/ MediaCentre/HotTopics/Documents/JointStatement_COVID-19.pdf(indicating thatwHO and Imo called upon all states to respect free pratique during the CoviD-19 pandemic).

67 IHR, supra note 32, arts. 28(1)-(3); see, e.g., Press Release: Crew Member with COVID-19 (Coronavirus Disease 2019) Fully Recovers and Ship Resumes Normal Operations, MAR. \& Port Authority Sing. (Feb. 24, 2020), https://www.mpa.gov.sg/web/portal/ home/media-centre/news-releases/detail/e7a16c6a-fe5c-47bb-b9ad-o3538c6dgfao; Karen N. Scott, New Zealand: Regulating Shipping in Response to COVID-19, 5 AsIAPacific Journal of Ocean LaW \& Policy 351, 357-58 (2020) (stating the conditions of disembarkation for essential tasks).

68 IHR, supra note 32, art. 43; cf. Agreement on Maritime Transport Between the Governments of the Member Countries of the Association of Southeast Asian Nations and the Government of the People's Republic of China arts. 4, 16, Nov. 2, 2007.

69 Natalie Klein, International Law Perspectives on Cruise Ships and COVID-19, 11 JournaL of International Humanitarian Legal Studies 282 passim (2020).

70 Henrik Ringbom, Legalizing Autonomous Ships, 34 Ocean Yearbook Online 429, 448 (2020).

71 Collection of Sources on Entry into Port Under Force Majeure, U.S. Dep't State (2009), https://2001-2009.state.gov/s/l/2007/112701.htm; MoRrIsON, supra note 46, at 75-126; Terje Lobach, Advances in Port State Control Measures, in Fish Piracy: Combating Illegal, Unreported and Unregulated Fishing 291, 296 (oecd ed., 2004); Alexander Proelss, Rescue at Sea Revisited: What Obligations Exist Towards Refugees?, 2008 Scandinavian Institute of Maritime LaW Yearbook 1, 22-25; Aldo Chircop, Assistance at Sea and Places of Refuge for Ships: Reconciling Competing Norms, in JuRisdiction over Ships: Post-UNCLOS Developments in the LaW of the SEA 140, 140 (Henrik Ringbom ed., 2015); UNCLOS, supra note 5, arts. 18(2), 39(1)(c), 45, $52(1), 54$. 
This customary law right of entry to port is recognized in soft law instruments, such as the International Plan of Action to Prevent, Deter, and Eliminate Illegal, Unreported and Unregulated Fishing (IPOA-IUU).$^{72}$ It is vicariously recognized in treaties, such as PSMA, which would, but for the situation of force majeure or distress, impose obligations upon port states to deny access. ${ }^{73}$ Other instruments also implicitly recognize this exceptional right of entry by limiting the port states' obligations to vessels "voluntarily in port". ${ }^{74}$ Similarly, treaties that promote compliance with international standards through port state control will often exempt those vessels in port due to distress or force majeure. ${ }^{75}$

This exception will limit the port state's right to deny entry, although a place of refuge will not normally require port entry but rather a sheltered area along the coastline. ${ }^{76}$ Requests for access to a place of refuge may arise in other contexts, such as a situation presenting an environmental hazard, ${ }^{77}$ or economic considerations, such as the otherwise total loss of an abandoned vessel and cargo. ${ }^{78}$ However, in such cases there is no obligation under international law for the coastal state to grant permission to enter a place of refuge, nor are places of refuge necessarily a port. ${ }^{79}$ Of course, states remain at liberty to grant

72 Food and Agriculture Organization of the United Nations (FAO), International Plan of Action to Prevent, Deter, and Eliminate Illegal, UNREPORTED AND UNREgULATED FISHING 15 (2001). PSMA, supra note 6, art. 10.

74 FaO, Code of Conduct for Responsible Fisheries 41 (1995); UnfSA, supra note 28 , art. $23(2)$.

75 Work in the Fishing Convention art. 4(2)(d), 43(2), June 14, 2007, ILO Doc. No. 188; 1993 Torremolinos Protocol Relating to the 1977 Torremolinos International Convention for the Safety of Fishing Vessels art. 5(2), Apr. 2, 1993, 2001 Tractatenblad 168; SOLAS, supra note 24, art. IV; e.g., Chircop, supra note 71, at 149-50.

76 Iм0, Guidelines on Places of Refuge for Ships in Need of Assistance I 1.19, IMо Doc. A 23/ Res.949 (Mar. 5, 2004) ("[A] place where a ship in need of assistance can take action to enable it to stabilize its condition and reduce the hazards to navigation, and to protect human life and the environment").

77 Id. ๆ 1.18.

78 ACT Shipping (Pte) Ltd. v. Minister for the Mar. [1995] 3 I.R. 406 (H. Ct.) 424-26 (Ir.) ("If safety of life is not a factor, then there is a widely recognized practice among maritime states to have proper regard to their own interest and those of their citizens in deciding whether or not to accede to any such [safe haven] request"); John E. Noyes, Places of Refuge for Ships, 37 Denver Journal of International Law \& Policy 135, 138 (2008) (noting that some authors maintain other interests, including economic, remain in explaining the customary law rule of access to port or other places of refuge when in distress).

79 IMO, supra note 76, ๆף 1.19, 3.12, 3.13; ACT Shipping (Pte) Ltd. [1995] 3 IR 424-26 (explaining that at most one may raise a judicial review challenge in domestic law, but the decision to refuse access would have to have been patently unreasonable or irrational); 
broader rights of entry into port for vessels in distress than their customary law obligations require. For example, the Convention concerning Fishing in the Black Sea provided Contracting Parties' vessels with access to designated ports of refuge "to shelter from bad weather or in case of damage". 80

The port/coastal state evaluating the necessity of shelter for the preservation of human life will balance the interests raised by the vessel's circumstances against its own interests. ${ }^{81}$ When granting humanitarian access further entry conditions may therefore be applied, ${ }^{82}$ although illegal activity alone cannot be grounds for denial of entry. ${ }^{83} \mathrm{~A}$ common example would be imposing financial security conditions for entry. ${ }^{84}$ Decisions about the necessity of entry, or lack thereof, should be based on objective facts as balanced against the port state's interests. ${ }^{85}$

Essentially, port states should exercise due diligence in reviewing, on a case-by-case basis, whether an entry right applies. ${ }^{86}$ The port state determines whether force majeure or distress is demonstrated, ${ }^{87}$ which domestic interests are threatened, the weight to be given to competing interests, and any decision upon entry and upon what conditions. For vessels granted an exceptional right of access to port and acting in full compliance with the condition of entry imposed, the port services they can access are similarly limited. Subject to availability, the port state is obligated to provide access to port services

see also Schatz \& Fantinato, supra note 45 , at 761-64, 768-69 (indicating that domestic law may also exclude criminal liability for breaching orders denying port entry).

80 Convention Concerning Fishing in the Black Sea arts. 2-3, July 7, 1959, 377 U.N.T.S. 203.

81 Jon M. Van Dyke, Safe Harbour, 2010 Max Planck Encyclopedia of Public International LaW \\4-6 (2010); see Imo, supra note 76, pmbl.; see Henrik Ringbom, You Are Welcome, but... Places of Refuge and Environmental Liability and Compensation, with Particular Reference to the EU, 2004 CMI YеArвоок 208, 209-10; see Noyes, supra note 78 , at $140-42$.

82 Ringbom, supra note 81 , at 209-10 (recognizing the right to impose conditions); e.g., PSMA, supra note 6, art. 10; e.g., SOLAS, supra note 24, art. v(b); e.g., Salvage Convention, supra note 27 , art. 11 .

83 Eric Van Hooydonk, The Obligation to Offer a Place of Refuge to a Ship in Distress, $2003 \mathrm{CMI}$ YEARBOOK 403, 408 (2003).

84 Noyes, supra note 78, at 139; e.g., Sibulelo Seti, Places of Refuge for Ships in Distress: The South African Approach and Challenges, 14 TransNav 67,69 (2020) (indicating that in South Africa an insurance coverage requirement plays a pivotal role in balancing competing interests when granting entry into port).

85 Van Hooydonk, supra note 83 , at 407 .

86 Chircop, supra note 71, at 161-62.

87 Proelss, supra note 71 , at 25 . 
essential to preserving health and safety. ${ }^{88}$ Beyond this, services are provided at the discretion of the port state.

In the near future, the right of refuge may need to adapt to forthcoming technological revolutions. As Chircop highlights, unmanned vessels will trigger distress cases threatening serious transboundary environmental or economic damage, but without raising humanitarian concerns. ${ }^{89} \mathrm{~A}$ right of entry in distress should necessarily either evolve to address these primarily environmental concerns, or simply fade away as remote operators move ashore and humanitarian concerns disappear.

\section{$2.5 \quad$ Sub-Conclusion}

It was seen that the jurisdiction to regulate access to port was legally valid without recourse to the principles of state jurisdiction. Port states have an exceptional domaine réservé-based jurisdiction to prescribe conditions of entry and enforce these through denial of access (subsections 2.1-2.3)). Within the law of the sea, the principal restriction on this jurisdiction is those rare cases where a vessel in distress, or compelled by force majeure, requires access to a port in order to preserve human life. In such cases, a port state may condition but not outright prohibit port entry and may condition but not outright prohibit access to port services that are essential to the health and safety of the crew and passengers (subsection 2.4).

A right of port entry, therefore, limits the port state's jurisdiction on port entry and services. However, this right may also impact the wider port state jurisdiction to enforce offenses utilising a port state nexus. Certain laws are inapplicable when force majeure or distress entry occurs. ${ }^{90}$ While the scope of this limitation is unsettled, inapplicable laws would include those "in connection with actions to relieve the distress". ${ }^{91}$ Rules closely tied to voluntarily entering a state, such as customs law, are inapplicable to vessels in port due

88 PSMA, supra note 6, arts. 10, 11(2)(a), 18(2).

89 Aldo Chircop, Testing International Legal Regimes: The Advent of Automated Commercial Vessels, 6o German Yearbook of International LaW 109 (2017).

90 Ted L. McDorman, Regional Port State Control Agreements: Some Issues of International Law, 5 Ocean \& Coastal Law Journal 207, 210 (2000); Robin Rolf Churchill \& Alan Vaughan Lowe, The Law of the Sea 68-69 (2d ed. 1988); Dyke, supra note 81, \ๆ 12-14 (suggesting limitations may be relegated to comity).

91 U.S. DeP't State, supra note 71; contra Jianye Tang, The Agreement on Port State Measures: A Commentary, 2009 China OCEAns Law Review 312, 324 ("the port State's duties only extend as far as not to deny their entry into its port, but it is not obligated to offer any port services"). 
to force majeure or distress. ${ }^{92}$ Enforcement of treaty-based jurisdiction under Article 218 of UNCLOS is limited by a requirement, among others, that proceedings may only be instituted "[w]hen a vessel is voluntarily within a port or at an off-shore terminal." ${ }^{33}$ Beyond these limited cases of offenses closely tied to entry or treaty-based port state jurisdiction, comity may discourage the enforcement of port state laws but port states are not limited as a matter of international law. ${ }^{94}$

\section{$3 \quad$ Historic Fishing Rights and Associated Rights}

Much like port state jurisdiction discussed above, the law on the acquisition and limits of historic fishing rights is found outside of UNCLOS and within the residual general international law. ${ }^{95}$ As this article proposes that a second exceptional customary right of access to port can be found in the doctrine of

92 Yang, supra note 6o, at 66; David J. Doulman \& Judith Swan, A Guide to the Background and Implementation of the 2009 FAO Agreement on Port State Measures to Prevent, Deter and Eliminate Illegal, Unreported AND UnRegulated Fishing 45 (2012); Oliver, supra note 52, at 292; Case C-286/9o, Anklagemyndigheden v. Poulsen, 1992 E.C.R. I-6o34, I-6o46 (distinguishing the inapplicability of entry-related laws from the possible continued application of other territorial-based laws).

93 UnClos, supra note 5, arts. 218(1), (3); see also Ho-Sam Bang, Port State Jurisdiction and Article 218 of the UN Convention on the Law of Sea, 40 Journal of Maritime Law \& Commerce 291, 300 (2009); Doris König, Article 218, in United Nations Convention on the Law of the Sea: A Commentary 1487 (Alexander Proels ed., 2017); Denning Metuge \& Patrick Vrancken, Port State Jurisdiction in Terms of Article 218 of the United Nations Convention on the Law of the Sea: A South African Perspective, in AFrICAN Perspectives on Selected Marine, Maritime and International Trade LAW TopICs 71, 81 (Patrick Vrancken \& Charl Hugo eds., 2020) (explaining that implementation remains optional, as seen in the lack of domestic provisions in South Africa).

94 Authors disagree on whether Article 220 of UNCLOS may limit port state jurisdiction by referring to vessel voluntarily in port. Compare Erik J. MolenaAr, Coastal State Jurisdiction over Vessel-Source Pollution 187 (1998), with Ahmed Adham Abdulla, Flag, Coastal and Port State Jurisdiction over the Prevention of Vessel Source Pollution in International Law: Analysis of Implementation by the Maldives 171 (2011) (Ph.D. dissertation, University of Wollongong) (on file with Australian National Centre for Ocean Resources and Security, Faculty of Law, University of Wollongong). Arguably, as the pollution incident occurred in the territorial sea or EEZ, unconnected to the compelled port entry, enforcement should not be limited.

95 UNCLOS, supra note 5, pmbl.; see also id. art. 2(3) for laws in the territorial sea; see also In $r e$ The South China Sea Arbitration (Phil. v. China), 33 R.I.A.A. 153, 470-71 (Perm. Ct. Arb. 2016) [hereinafter scs Award]. 
historic fishing rights, and an overview of contemporary historic fishing rights is necessary for context and scope.

\subsection{Historic Fishing Rights ${ }^{96}$}

UNCLOS explicitly recognizes several regimes of historic waters. ${ }^{97}$ Historic waters involve "claims of sovereignty over maritime areas derived from historical circumstances". ${ }^{98}$ Alternatively, and significantly narrower, UNCLOS establishes treaty-based "traditional fishing rights" in archipelagic waters which were formally high seas, while historic fishing rights in archipelagic waters which were formally territorial seas are preserved. ${ }^{99}$ No historic fishing access rights in the EEZ are provided. Coastal states have exclusive jurisdiction over access to living resources in their EEz. At most, coastal states shall take into account historic fishing in the EEz if and when allocating catch surplus to foreign states. ${ }^{100}$ Any resulting economic dislocation in historic fishing or researching states is just one of many non-exhaustive factors the coastal state shall weigh under Article 62(3) of UNCLOS when allocating catch surplus to foreign states. ${ }^{101}$

UNCLOS is largely silent on defining or elaborating the broader conception and acquisition of historic rights, ${ }^{102}$ although general requirements including consistency with UNCLOS and general international law, as well as following the UnCLOS drafters' intent, shall apply. ${ }^{103}$ The South China Sea Arbitration

96 The author is indebted to Valentin Schatz for sharing an advance draft of his Ph.D. manuscript's chapter on historic fishing rights.

97 UNCLOS, supra note 5, arts. 10(6), 15, 46, 298(1)(a)(i); Continental Shelf (Tunis. v. Libya), Judgment, 1982 I.C.J. 18, ๆ 100 (Feb. 24) ("It seems clear that the matter continues to be governed by general international law [which] does not provide for a single 'régime' for 'historic waters' or 'historic bays', but only for a particular régime for each of the concrete, recognised cases of 'historic waters' or 'historic bays'”).

$98 \quad$ scs Award, supra note 95, at 271.

99 UNCLOS, supra note 5 , art. 51(1).

$100 \quad$ Id. arts. $47(6), 62(3)$.

101 William T. Burke, The Law of the Sea Convention Provisions on Conditions of Access to Fisheries Subject to National Jurisdiction, 63 Oreg ON LAW Review 73, 102-03 (1984); SCS Award, supra note 95, at 277-78, 437.

102 Seokwoo Lee \& Lowell Bautista, Historic Rights, in The Development of the Law of the Sea Convention: The Role of International Courts and Tribunals 244, 244-45 (Øystein Jensen et al. eds., 2020).

103 See sCs Award, supra note 95, at 290-91 (upon ratification of UNCLOS states "relinquished the freedoms of the high seas that it had previously utilised with respect to the living and non-living resources of certain sea areas which the international community had collectively determined to place within the ambit of the exclusive economic zone of other States"). 
Award (SCS Award) reaffirms that "historic rights" encompasses both historic waters and historic rights falling short of a claim to sovereignty, such as historic fishing rights. ${ }^{104}$ Different historic rights require different thresholds of necessary practice and acquiescence to be established. Nonetheless, the process of acquisition is similar:

$[\mathrm{H}]$ istoric waters are merely one form of historic right and the process is the same for claims to rights short of sovereignty [...] historic rights are, in most instances, exceptional rights. They accord a right that a State would not otherwise hold, were it not for the operation of the historical process giving rise to the right and the acquiescence of other States in the process (emphasis added). ${ }^{105}$

The distinguishing factor between historic waters, historic fishing rights, and traditional fishing rights is the extent of exceptional right(s) claimed. Respectively, this extent ranges from a historic right to sovereignty (a defined area: encompassing all the territorial sovereign's rights); a historic right to fishing short of claiming sovereignty (a defined area and defined marine living resource(s): encompassing non-exclusive rights of access and utilization); and a historic right to fishing short of claiming sovereignty and limited to traditional communities and/or methods (a defined area, defined marine living resource(s)and defined actors: encompassing non-exclusive rights of access and utilization). Artisanal fishing rights are, in turn, a more narrowly defined historic fishing right than traditional fishing rights. ${ }^{106}$ In short, "the scope of a claim to historic rights depends upon the scope of the acts that are carried out

$104 I d$. at $270-71$ (citing previous recognition of the distinction between claims to historic fishing rights and the question of sovereignty over the area in which the fishery is located); see Maritime Delimitation and Territorial Questions Between Qatar and Bahrain (Qatar v. Bahr.), Judgment, 2001 I.C.J. 40, \ 236 (Mar. 16); Continental Shelf, 1982 I.C.J. 18, ๆ 100. Furthermore, see Territorial Sovereignty and Scope of the Dispute (Eri. v. Yemen), 22 R.I.A.A. 209, 244 (Perm. Ct. Arb. 1998) (comparing historic rights to a servitude in property law).

105 scs Award, supra note 95, at 288-89.

$106 I d$. at 470 ("In keeping with the fact that traditional fishing rights are customary rights, acquired through long usage, the Tribunal notes that the methods of fishing protected under international law would be those that broadly follow the manner of fishing carried out for generations: in other words, artisanal fishing in keeping with the traditions and customs of the region"); see id. at 467 (explaining that if an artisanal fishing right is established, the extent of the historic fishing right excludes "industrial fishing"); $c f$. Dispute Regarding Navigational and Related Rights (Costa Rica v. Nicar.), Judgment, 2009 I.C.J. 213, ๆ 141 (July 13) (stating a comparable discussion on "subsistence fishing" in a river context, subsistence being defined by what is excluded). 
as the exercise of the claimed right".107 Figure 1 (below) captures this diversity in scope and terminology:

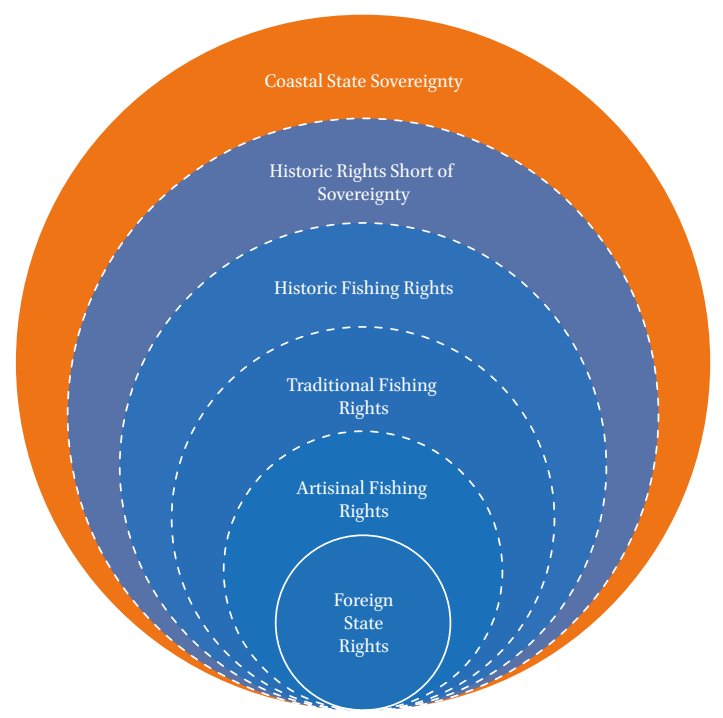

FIGURE 1

Extent of historic right exceptions to coastal state sovereignty

A coastal state's acquiescence cannot be presumed for any activities beyond the historic practices, and thus international law recognizes diverse practices resulting in diverse historic rights. ${ }^{108}$ In cases where sovereignty is disputed, as in most international jurisprudence to date, exceptionalism has been evident among all potential claimant coastal states. Communal exceptionalism reiterates that the eventual resolution of which state has sovereignty over the territorial sea will not prejudice the continuity of the other states' historic fishing rights.

Historic fishing rights are exceptional. Exceptionalism mandates a continuous and effective exercise of fishing, combined with the acquiescence of the coastal state who would otherwise exercise full sovereignty over the fishery. Exceptionalism, therefore, dictates that customary historic fishing rights can only be established in the internal waters or territorial sea of a foreign state. ${ }^{109}$

107 scs Award, supra note 95, at 289.

108 E.g., Maritime Delimitation and Territorial Questions Between Qatar and Bahrain, 2001 I.C.J. 40, ๆ $235^{-3} 6$ (stating that in areas of overlapping entitlements, traditional pearl diving rights common to all coastal populations and regulated by the fishers' state of nationality may develop).

109 Joanna Mossop, Can the South China Sea Tribunal's Conclusions on Traditional Fishing Rights Lead to Cooperative Fishing Arrangements in the Region?, 3 As IA-PACIFIC JourNAL of OCEAN LAw \& Policy 210, 227-28 (2018); contra Sophia Kopela, Historic Titles and 
Schatz takes this exceptionalism requirement one step further, arguing that historic fishing rights could be further limited to the belt of the territorial sea that was established before the conclusion of UNCLOS - i.e. the limited waters where sovereignty and therefore acquiescence of the coastal state could historically have been established. ${ }^{110}$

As the scs Award held, not only are historic fishing rights in the EEZ, continental shelf, high seas, or the Area not expressly permitted in UNCLOS, ${ }^{111}$ but Articles $56,58,62,77$, and 309 of UNCLOS illustrate that a continued claim to historic fishing rights in a foreign state's EEZ or continental shelf (without coastal state consent) would be incompatible with UNCLOS. ${ }^{112}$ This position is widely shared in the region, with Indonesia, for example, citing the SCS Award and affirming the lack of historic rights in the EEZ or continental shelf postUNCLOS. ${ }^{113}$ As Schatz highlights, a "host of EEz fisheries access agreements concluded during the 1970s [...] provided for a gradual phase-out of historic foreign fishing activity instead of recognizing permanent historic rights".114

Concerning high seas fishing, this is an exercise of existing freedom, ${ }^{115}$ thus lacking any exceptionalism to establish historic rights. ${ }^{116}$ Indeed, as a condition of establishing the UNCLOS novelty of archipelagic waters, those states immediately adjacent to archipelagic waters successfully negotiated UNCLOs-based

Historic Rights in the Law of the Sea in the Light of the South China Sea Arbitration, 48 OCEAN DEVELOPMENT \& INTERNATIONAL LAW 181, 192-96 (2017) (stating some persuasive arguments that historic rights are preserved regardless of maritime zone), and Sophia Kopela, Historic Fishing Rights in the Law of the Sea and Brexit, 32 LeIden Journal of INTERNATIONAL LAW 695, 704-08 (2019).

110 Valentin J. Schatz, Access to Fisheries in the United Kingdom's Territorial Sea After its Withdrawal from the European Union: A European and International Law Perspective, 9 Goettingen Journal of International LaW 457, 488-9o (2019) (indicating that if in 1982 the UK territorial sea was only $3 \mathrm{~nm}$, historic fishing rights could not have been acquired in the $3^{-12 n m}$ belt which was at the time part of the UK's exclusive fishery zone).

111 scs Award, supra note 95, at 275.

112 Id. at $276-79,283,287$.

113 Permanent Mission of Indonesia to the U.N., Letter dated May 26, 2020 from the Permanent Mission of the Republic of Indonesia to the United Nations addressed to the Secretary General of the United Nations, U.N. Doc. 126/POL-703/V/20 (May 26, 2020).

114 Valentin J. Schatz, The International Legal Framework for Post-Brexit EEZ Fisheries Access Between the United Kingdom and the European Union, 35 THE InTERNATIONAL JournaL OF MARINe \& COASTAL LAW 133, 150-51 (2020).

115 UNCLOS, supra note 5 , arts. 87(1)(e), 116.

116 sCs Award, supra note 95, at 289-9o; Robert Beckman, 'Deliberate Ambiguity' and the Demise of China's Claim to Historic Rights in the South China Sea, 1 AsIA-PACIFIC JournaL of OCEAN LAW \& Policy 164, 180-81 (2016). 
'traditional fishing rights' to preserve their former high seas fishing therein. ${ }^{117}$ Finally, the position of certain states in the ongoing BBNJ Agreement negotiations has brought uncertainty to the exclusion of fisheries from the Area's regime, ${ }^{118}$ but for the purposes of this article former technological limitations mean that historic fishing rights therein are highly unlikely. ${ }^{119}$

\subsection{Associated Rights and Access to Port}

Historic fishing rights are not absolute. Reasonable regulation by the coastal state may apply and international courts and tribunals have emphasized the coastal state's right to impose environmental regulation. ${ }^{120}$ The extent of protection due to historic fishing states is established on a case-by-case basis. ${ }^{121}$ However, the concept of associated rights may further limit a coastal state's right to regulate foreign vessels or persons exercising historic fishing rights. Associated rights were recognized and defined in the Eritrea/Yemen Award, ${ }^{122}$ whereby the Tribunal held:

In order that the entitlements be real and not merely theoretical, the traditional regime has also recognised certain associated rights. ${ }^{123}$

What is more, the Tribunal then affirmed an associated right of access to port and port services for historic fishers in the Red Sea. First, Stage I of proceedings recognized that historic practices included both the fishers' access to islands as a refuge from poor weather and the fishers' access to each state's coastal markets without a need for authorization. ${ }^{124}$ Second, Stage II then confirmed:

\footnotetext{
117 unclos, supra note 5, arts. 47(6), 51; Hugo Caminos \& Vincent P. Cogliati-Bantz, The legal Regime of Straits: Contemporary Challenges and Solutions 268-80 (2014).

118 UNCLOS, supra note 5, arts. 133-91.

119 SCs Award, supra note 95, at 289.

120 Id. at 471; e.g. Dispute Regarding Navigational and Related Rights, 2009 I.C.J. 213, ๆ 141.

121 SCs Award, supra note 95, at 471-72 (stating that the Tribunal found it unnecessary to explore the limits of protection as the extended and complete prevention of the exercise of historic fishing rights was "not compatible with the respect due under international law to the traditional fishing rights").

122 See Barbara Kwiatkowska, The Eritrea-Yemen Arbitration: Landmark Progress in the Acquisition of Territorial Sovereignty and Equitable Maritime Boundary Delimitation, 32 Ocean Development \& International LaW 1 passim (2001) (providing literature discussion of all aspects of the Award); Constance Johnson, Case Analysis: Eritrea - Yemen Arbitration, 13 Leiden Journal of International LaW 427 (2000).

123 Maritime Boundary Delimitation (Eri./Yemen), 22 R.I.A.A. at 36o.

124 Territorial Sovereignty and Scope of the Dispute (Eri./Yemen), 22 R.I.A.A. at 244.
} 
There must be free access to and from the islands concerned - including unimpeded passage through waters in which, by virtue of its sovereignty over the islands, Yemen is entitled to exclude all third Parties or subject their presence to licence, just as it may do in respect of Eritrean industrial fishing. This free passage for artisanal fishermen has traditionally existed not only between Eritrea and the islands, but also between the islands and the Yemen coast. The entitlement to enter the relevant ports, and to sell and market the fish there, is an integral element of the traditional regime. [...] Eritrean artisanal fisherman fishing around the islands awarded to Yemen have had free access to Maydi, Khoba, Hodeidah, Khokha and Mocha on the Yemen coast, just as Yemeni artisanal fishermen fishing around the islands have had an entitlement to unimpeded transit to and access to Assab, Tio, Dahlak and Massawa on the Eritrean coast. Nationals of the one country have an entitlement to sell on equal terms and without any discrimination in the ports of the other (emphasis added $)^{125}$

Historic fishing regimes may therefore have application beyond the maritime zone in which the fishery is located, including associated rights in the ports of foreign states. ${ }^{126}$ An associated right to access foreign ports will be an exceptional restriction on the sovereignty of port states to otherwise oppose access by foreign vessels. ${ }^{127}$ Again, associated rights may also be subject to coastal state - or port state - regulation. This regulation may not however result in the denial of the right of access without the consent of the fishers' state of nationality. ${ }^{128}$ Finally, the Eritrea/Yemen Award's doctrinal contribution comes with a considerable caveat, namely critiques on the facts, including that the

\footnotetext{
125 Maritime Boundary Delimitation (Eri./Yemen), 22 R.I.A.A. at 36o.

126 Id. at 361 ("The traditional fishing regime operates throughout those waters beyond the territorial waters of each of the Parties, and also in their territorial waters and ports, to the extent and in the manner specified in paragraph 107").

127 See Nuno Sérgio Marques Antunes, The 1999 Eritrea-Yemen Maritime Delimitation Award and the Development of International Law, 5o International \& Comparative LaW QUARTERLY 299, 305 (2001) (recognizing these conditions for state sovereignty).

128 Territorial Sovereignty and Scope of the Dispute (Eri./Yemen), 22 R.I.A.A. at 24O; Iyob Tsehaye et al., Rapid Shifts in Catch Composition in the Artisanal Red Sea Reef Fisheries of Eritrea, 86 Fisheries RESEARCH 58, 59 (2007) (stating that concerns have been expressed over unreported catch in Eritrea heading to Yemen, contributing to a lack of effective assessment and management of artisanal fisheries).
} 
finding of an associated right of access to port goes beyond what the parties requested. ${ }^{129}$

International courts and tribunals have not recognized any further explicit cases of historic access to port as an associated right. ${ }^{130}$ Interestingly, the $s c s$ Award did distinguish access rights from fishing rights. ${ }^{131}$ If, as the $s c s$ Award reasons, a historic right of access to the territorial sea can limit a coastal state's territorial sovereignty, there is no additional principle of international law that prevents a historic right of access to port as limiting a port state's sovereignty. Equally, if UNCLOS essentially preserves the historic territorial sea regime and its historic fishing rights, ${ }^{132}$ then associated rights of port entry are also preserved because UNCLOS did not introduce any meaningful novelties to the regime of internal waters.

Nonetheless, an associated right is an additional historic right and therefore must independently meet the exceptionalism requirement. A sufficient degree of unhindered access to port by historic fishing vessels, demonstrative of the acquiescence of the port state, must have occurred. It is the very rejection of a general right of port entry (subsection 2.4) which allows for the possibility of a historic customary law right of port entry.

However, if a customary historic right of access to port may only be an associated right, then practice is clearly limited to exceptional cases where an exceptional historic fishing right is also first established. For example, a convenient and historic use of foreign ports to support high seas fishing could never establish a historic right of port access because no historic fishing rights - to which port access could be 'associated' - could crystalize.

129 Peter Dutton, Testing the Boundaries: A Research Report for the Maritime Dispute Resolution Project 41-42 (2019). Findings on historic fishing rights in the EEZ and the entirety of the territorial sea are also inconsistent with the exceptionalism requirement.

130 But see, Land, Island and Maritime Frontier Dispute (El Sal./Hond.), Judgment, 1992 I.C.J. 351, 412 (Sept. 11) (recognizing historic access and innocent passage rights in a shared historic bay, which if it should be delimited, would then be internal waters subject to historic rights of innocent passage for the purposes of accessing the ports of the three coastal states); Clive R. Symmons, The Types of Waters to Which Historic Claims may be Made, in Historic Waters and Historic Rights in the LaW of the Sea: A Modern Reappraisal 63, 92 (2d ed. 2019).

131 SCS Award, supra note 95, at 271 ("Historic rights may include sovereignty, but may equally include more limited rights, such as fishing rights or rights of access, that fall well short of a claim of sovereignty.").

132 Mossop, supra note 109, at 220-22 (succinctly stating the Tribunal's reasoning). 
Exceptional rights have, by definition, a narrow future in international law. As customary historic fishing rights progressively extinguish, ${ }^{133}$ so too will any associated right of access to port. ${ }^{134}$ Alternatively, historic customs of port entry could be incorporated into a treaty which, either immediately (if such an intention can be established), or upon an extended period of exercising port access under the said treaty, extinguishes the custom. ${ }^{135}$ The exceptional historic consent to port entry would be replaced by the consent to access port established in the treaty. In a different - but comparable - context, agreements reflecting the treaty-based rights of Articles 47(6) or Article 51(1) of UNCLOS, such as seen between Indonesia and Malaysia, may include associated rights of access to territories and resupply, akin to port access. ${ }^{136}$

An example from Australia may nonetheless be suggestive of a historic fishing right and an associated customary right of access to port continuing in parallel to a treaty-based framework. ${ }^{137}$ The Torres Strait Treaty provides for a

133 E.g. scs Award, supra note 95, at 471 (stating that concerning traditional fishing rights, coastal states may assess "the scope of traditional fishing to determine, in good faith, the threshold of scale and technological development beyond which it would no longer accept that fishing by foreign nationals is traditional in nature").

134 Conceptually - but not yet seen in practice - a historic right of access could develop as an independent historic right. To achieve a fair and just result (as opposed to any historic claims) a sui generis freedoms of communication regime applies in the "Junction Area" of Croatia's territorial sea, realizing "access to and from Slovenia's ports and waters"; In re Arbitration Between the Government of Republic of Croatia and Government of Republic of Slovnia (Croat./Slovn.), PCA Case Repository Case No. 2012-04, ๆף 1122-33 (Perm. Ct. Arb. 2017).

135 See, e.g., Memorandum of Understanding Between the Government of Australia and the Government of the Republic of Indonesia Regarding the Operations of Indonesian Traditional Fishermen in Areas of the Australian Exclusive Fishing Zone and Continental Shelf, Austl.-Indon., If 3(b), Nov. 7, 1994 (treaty-based rights for foreign fishing vessels to continue landing for resupply, which is akin to granting port entry and service rights); Practical Guidelines for Implementing the 1974 Memorandum of Understanding, Agreed Apr. 29, 1989 at 5 (1989), reprinted in 12 Australian Year Book of International LAW 369 (1992).

${ }_{13}$ See Treaty Between Malaysia and the Republic of Indonesia Relating to the Legal Regime of Archipelagic State and the Rights of Malaysia in the Territorial Sea and Archipelagic Waters as well as in the Airspace Above the Territorial Sea, Archipelagic Waters and the Territory of the Republic of Indonesia Lying Between East and West Malaysia, Indon.-Malay., art. 14(1)(c), Feb. 25, 1982 (agreement to enter into arrangements on the utilization of certain Indonesian islands for shelter and resupply by Malaysian traditional fishing vessels in distress or emergency); CAMinos \& CogLiATI-BANTZ, supra note 117, at $275^{-8}$ o.

137 Int'l Law Comm'n, Rep. on the Work of its Seventieth Session, U.N. Doc. A/73/10, at 143-46 (2018); e.g., Chagos Mar. Prot. Area Arbitration (Mauritius v. U.K.), 31 R.I.A.A. 359, $55^{1}$ (Perm. Ct. Arb. 2015) (Mauritius, for one, claimed fishing rights in the Chagos Archipelago's 
Protected Zone which seeks to protect the traditional way of life of traditional inhabitants. ${ }^{138}$ Apart from preserving traditional fishing, the Torres Strait Treaty also protects freedom of movement in the area related to traditional activities, such as the movement for the purposes of "barter and market trade".139 This is reaffirmed in Australia's Torres Strait Fisheries Act 1984 whereby the offense of unauthorized landing includes an exception for "fish that were taken in the course of traditional fishing and landed at that place for the purpose of the performance of traditional activities". 140 The language of the Torres Strait Treaty suggests that the historic rights and obligations of each state and its nationals shall "continue" and are not replaced by the Torres Strait Treaty. ${ }^{141}$

\section{$4 \quad$ Conclusion}

One state's historic right is another state's restriction to sovereignty. Historic rights cannot be presumed, ${ }^{142}$ but must fulfill the exceptionalism requirement most recently reaffirmed in the SCS Award. By examining historic fishing rights and associated rights from the perspective of port state jurisdiction, this article has sought to demonstrate that the current consensus on access to ports should be refined by an additional exception, namely, any associated right of port entry for fishers exercising historic fishing rights. This is in addition to - and distinct from - the customary law right of access to port or another sheltered area when vessels are in distress or compelled by force majeure, to access port to preserve human life.

While the right of access for vessels in distress is a global custom, the right of access for historic fishers in the Eritrea/Yemen Award is limited to governing the rights and obligations between the port state and the fishers' state of nationality. The latter case is therefore a concrete example of the concept of bilateral customary international law, first recognized in the Right of Passage over Indian Territory. ${ }^{143}$ Historic fishing rights, and thus associated

territorial sea under both the Lancaster House Undertakings and as a historic customary right, but the Arbitral Tribunal did not address the historic rights claim).

138 Torres Strait Treaty, supra note 3, art. 10(3) (traditional inhabitants, traditional fishing and traditional activities in Article 1); see generally Stuart B. Kaye, Jurisdictional Patchwork: Law of the Sea and Native Title Issues in the Torres Strait, 2 Melbourne Journal of INTERNATIONAL LAW 381, 391 (2001).

139 Torres Strait Treaty, supra note 3, art. 1(1)(k)(iv).

140 Torres Strait Fisheries Act 1984 (Cth) s 5o(1) (Austl.).

141 Torres Strait Treaty, supra note 3, arts. 11-12.

142 See S.S. Lotus (Fr. v Turk.), Judgment, 1927 P.C.I.J. (ser. A) No. 10, at 18 (Sept. 7).

143 Right of Passage over Indian Territory (Port. v. India), Judgment, 196o I.C.J. 6, 37 (Apr. 12). 
rights (if inseverable), cannot generally be transferred to foreign states and their nationals. ${ }^{144}$ The associated right of access to port and port services will therefore remain a bilateral custom.

144 W. Michael Reisman \& Mahnoush H. Arsanjani, Some Reflections on the Effect of Artisanal Fishing on Maritime Boundary Delimitation, in LAW of THE SEA, Environmental LAW And Settlement of Disputes 629, 632 (Tafsir Malick Ndiaye \& Rüdiger Wolfrum eds., 2007). 